\title{
Effects of crude glycerin from waste vegetable oil in diets on performance and carcass characteristics of feedlot goats
}

\author{
Pin Chanjula ${ }^{1, *}$, and Anusorn Cherdthong ${ }^{2}$
}

* Corresponding Author: Pin Chanjula Tel: +66-74-558805, Fax: +66-74-558805,

E-mail: pin.@@su.ac.th

'Department of Animal Science, Faculty of Natural Resources, Prince of Songkla University, Songkhla 90112, Thailand

${ }^{2}$ Tropical Feed Resources Research and Development

Center (TROFREC), Faculty of Agriculture, Khon Kaen

University, Khon Kaen 40002, Thailand

\section{ORCID}

Pin Chanjula

https://orcid.org/0000-0002-3507-390X

Anusorn Cherdthong

https://orcid.org/0000-0002-8719-4404

Submitted Mar 13, 2017; Revised Aug 12, 2017; Accepted Aug 21, 2017
Objective: This experiment was conducted to investigate the effects of crude glycerin from waste vegetable oil (CGWVO) on performance, carcass traits, meat quality, and muscle chemical composition.

Methods: Twenty-four crossbred (Thai NativexAnglo Nubian) uncastrated male goats (16.8 \pm $0.46 \mathrm{~kg}$ body weight [BW]) were assigned to a completely randomized design and subjected to four experimental diets containing $0 \%, 2 \%, 4 \%$, and $6 \%$ of CGWVO $(63.42 \%$ of glycerol and $47.78 \%$ of crude fat) on a dry matter (DM) basis. The diets were offered ad libitum as total mixed rations twice daily. The feed intake, feeding behavior, growth performance, carcass and meat traits, and muscle chemical composition were evaluated.

Results: Based on this experiment, there were significant differences ( $p>0.05)$ among groups regarding DM intake, growth performance, and carcass traits where goats receiving $6 \%$ of CGWVO had lower daily DM intake, growth performance, and carcass traits than those fed on $0 \%, 2 \%$, and $4 \%$ of CGWVO. There were no effects of CGWVO on carcass length, carcass width, Longissimus muscle (LM) area, Warner-Bratzler shear force, $\mathrm{pH}$ and color of LM at 45 min after slaughter, as well as on other carcass cut and muscle chemical composition.

Conclusion: In conclusion, the addition of up to $4 \%$ of DM in the diets for crossbred finishing goats seems to be the most interesting strategy, since it promotes greatest animal performance. Moreover, this study was a suitable approach to exploit the use of biodiesel production from waste vegetable oil for goat production.

Keywords: By-product; Crude Glycerin; Waste Vegetable Oil; Growth Performance; Carcass Characteristic; Goat

\section{INTRODUCTION}

Rapid growth in biofuel production has led to increased prices of several agricultural commodities, including corn. Its high market price is driving livestock producers to search for alternative feed sources. Crude glycerin (CG) is the major byproduct of the conversion of vegetable oils, animal fats (first-use oil) and/or waste greases (second-use oil) into biodiesel [1]. Approximately $10 \%$ of the total volume of biodiesel produced becomes CG [1]. Rapid growth in biofuel production of Thailand has led to increasing feedstocks of CG, with a subsequent price reduction, making glycerin a potential high energy feed source for ruminants [2]. The use of CG as a substitute for energetic ingredients in animal feed has shown promising results for livestock in many species including swine, poultry, beef cattle, dairy cattle, goats, and sheep.

The inclusion of glycerin in ruminant diets modifies ruminal fermentation such as the acetate: propionate ratio, because CG is preferentially converted to propionate in the rumen, absorbed directly by ruminal epithelium or goes directly to the small intestine and is then converted to glucose in the liver [3]. Similarly, AbuGhazaleh et al [4] reported that CG was 
an appealing byproduct in feedlot diets because it was primarily converted to propionate in the rumen and acted as a precursor for glucose synthesis. However, recent studies have evaluated the effects of the inclusion of CG (up to $86 \%$ of glycerol) in diets on feed intake, performance, carcass, and meat quality of beef, dairy, goat and sheep with acceptable inclusions of $15 \%$ to $21 \%$ dry matter (DM), respectively $[2,5,6]$. Furthermore, most of the CG used in those studies was derived from vegetable oils (first-use oil) of castor bean, soybean, cottonseed, sunflower, rapeseed, canola, and palm oil. At present, a limited number of studies have evaluated the effects of CG originating from waste vegetable oils (CGWVO) that (seconduse oil) contained high crude fat and a low content of glycerin in diets fed to goats. Thompson and $\mathrm{He}$ [1] reported that nutritional data generated for the glycerin of the first-use oil samples showed that it was mostly carbohydrate and could reasonably be mixed with high protein meal and used as a feed supplement. They also found that giving the higher fat content of CGWVO could be used as a supplement for energy or fat in animal diets particularly in goats. The authors hypothesized that CGWVO containing $63.42 \%$ of glycerol and $47.78 \%$ of crude fat in DM basis [7] might be might be used as an energy source in the diet of feedlot finishing goats at concentrations of up to $6 \%$ on a DM basis without compromising animal performance, or carcass and meat quality traits of goats. Lage et al [8] noted linear decreases in feedlot performance and carcass characteristics of lambs when fed 6 and 12\% CG; however, no differences were noted between $0 \%$ and 6\% CG supplementation. To further evaluate the optimal amount of CGWVO in the diet of goats. Therefore, the objectives of this study were to evaluate the effects of CGWVO on animal performance, and carcass and meat quality traits while establishing an optimal feeding amount in goats fed diets containing corn grain.

\section{MATERIALS AND METHODS}

The trials were conducted at the Department of Animal Science, the Faculty of Natural Resources, Prince of Songkla University (PSU), Hat Yai Campus. All procedures involving animals in the metabolism and finishing studies were approved by the Animal Ethics Committee of Prince of Songkla University (record no. AEPSU 16/2558), based on the Ethical of Animal Experimentation of National Research Council of Thailand (NRCT).

\section{Animals, housing and experimental diets}

Twenty-four crossbred (Thai Native $\times$ Anglo Nubian) uncastrated male goats $(16.8 \pm 0.46 \mathrm{~kg}$ body weight $[\mathrm{BW}])$ and an initial average age of eight months were used in a completely randomized design and subjected to four experimental diets containing $0 \%, 2 \%, 4 \%$, and $6 \%$ of CGWVO $/ \mathrm{kg} \mathrm{DM}$ (Table 1 ). Animals were housed in individual pens $(1.0 \times 1.0 \mathrm{~m})$ indoors,
Table 1. Ingredient proportion and chemical composition of the experimental diets

\begin{tabular}{|c|c|c|c|c|}
\hline \multirow{2}{*}{ Item } & \multicolumn{4}{|c|}{ Dietary CGWVO (\% DM) } \\
\hline & 0 & 2 & 4 & 6 \\
\hline \multicolumn{5}{|l|}{ Ingredients (\%) } \\
\hline (GWVO') & 0.00 & 2.00 & 4.00 & 6.00 \\
\hline Ground corn & 43.00 & 41.00 & 39.00 & 37.00 \\
\hline Soybean meal & 20.93 & 21.56 & 21.83 & 22.78 \\
\hline Fish meal & 1.00 & 1.00 & 1.00 & 1.00 \\
\hline Leucaena leave meal & 4.87 & 4.24 & 3.50 & 3.02 \\
\hline Plicatulum hay ${ }^{2)}$ & 25.00 & 25.00 & 25.00 & 25.00 \\
\hline Molasses & 3.50 & 3.50 & 3.97 & 3.50 \\
\hline Salt & 0.20 & 0.20 & 0.20 & 0.20 \\
\hline Dicalcium phosphate & 0.30 & 0.30 & 0.30 & 0.30 \\
\hline Urea & 0.20 & 0.20 & 0.20 & 0.20 \\
\hline Mineral and vitamin $\mathrm{mix}^{3)}$ & 1.00 & 1.00 & 1.00 & 1.00 \\
\hline \multicolumn{5}{|c|}{ Analyzed nutrient content ${ }^{4)}(\%$ DM) } \\
\hline DM & 95.13 & 95.77 & 95.97 & 94.69 \\
\hline Ash & 5.32 & 5.57 & 5.62 & 5.98 \\
\hline $\mathrm{OM}$ & 94.68 & 94.43 & 94.38 & 94.02 \\
\hline $\mathrm{CP}$ & 16.65 & 16.67 & 16.49 & 16.51 \\
\hline $\mathrm{EE}$ & 1.95 & 3.61 & 4.71 & 6.06 \\
\hline NFC & 30.00 & 29.90 & 32.92 & 30.43 \\
\hline NDF & 46.08 & 44.25 & 40.26 & 41.02 \\
\hline ADF & 19.36 & 18.13 & 18.41 & 18.00 \\
\hline$A D L$ & 6.63 & 5.50 & 5.59 & 5.46 \\
\hline ME (Mcal/kg DM) & 2.65 & 2.66 & 2.67 & 2.67 \\
\hline
\end{tabular}

CGWVO, crude glycerin waste vegetable oil; $\mathrm{DM}$, dry matter; OM, organic matter; $C P$, crude protein; $E E$, ether extract; NFC, non-fiber carbohydrate; NDF, neutral detergent fiber; $A D F$, acid detergent fiber; $A D L$, acid detergent lignin; $M E$, metabolizable energy.

${ }^{1)}$ Contained $63.42 \%$ glycerol, $13.93 \%$ water, $0.47 \%$ sodium, and $4.38 \%$ methanol (Colorless, odorless, viscous liquid obtained from Specialized Research and Development Center for Alternative Energy from Palm Oil and Oil Crop, Faculty of Engineering, Prince of Songkla University, Hat Yai Campus, Songkhla Province, 90110, Thailand.

2) Paspalum plicatulum Michx.

${ }^{3)}$ Minerals and vitamins mixs (each kg contains): Vitamin A, 10,000,000 IU; Vita$\min \mathrm{E}, 70,000 \mathrm{IU} ;$ Vitamin D, 1,600,000 IU; Fe, $50 \mathrm{~g} ; \mathrm{Zn}, 40 \mathrm{~g} ; \mathrm{Mn}, 40 \mathrm{~g} ; \mathrm{Co}, 0.1 \mathrm{~g}$; $\mathrm{Cu}, 10 \mathrm{~g} ; \mathrm{Se}, 0.1 \mathrm{~g} ; \mathrm{l}, 0.5 \mathrm{~g}$.

4) Based on analysis of composite feed sample.

with individual feed bunks and collective waterers. Animals were submitted to one of the four experimental treatments for $14 \mathrm{~d}$ adaptation period.

The experimental total mixed rations (TMR) diets were formulated to be isonitrogenous at $16 \% \mathrm{DM}$ of crude protein (CP) and isocaloric at $2.7 \mathrm{Mcal} / \mathrm{kg} \mathrm{DM}$ (on a metabolizable energy basis) to meet or exceed the NRC [9] requirements of growing goats (Table 1). The CGWVO used in this study originated from waste vegetable oils of rice bran, soybean, palm oil, and sunflower. CGWVO was produced by methylic route and obtained from the Faculty of Engineering, Prince of Songkla University, Songkhla Province, Thailand. The composition of the CGWVO is presented in Table 2. CGWVO from single batch was added to the total TMR as liquid. 
Table 2. Physical-chemical composition of crude glycerin from waste vegetable oil (CGWVO ${ }^{1,2)}$ ) included in the experimental diets

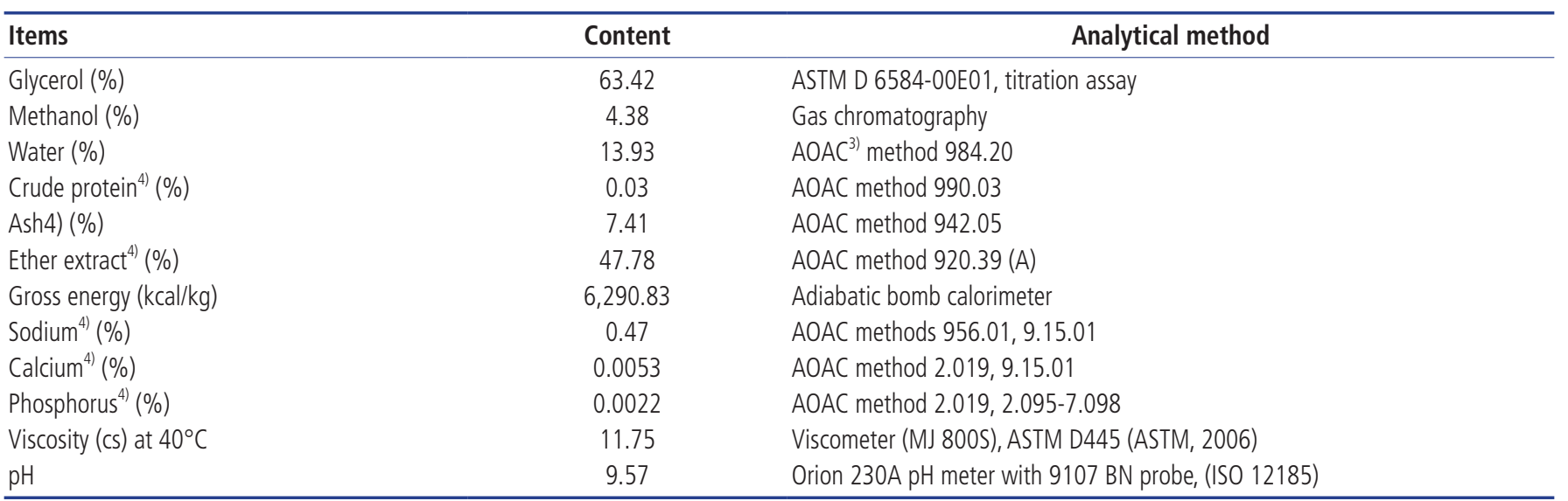

1) CGWVO was obtained from Specialized Research and Development Center for Alternative Energy from Palm Oil and Oil Crop, Faculty of Engineering, Prince of Songkla University, Hat Yai Campus, Songkhla Province, 90110, Thailand.

${ }^{2)}$ Analysis by Central Laboratories (Songkhla, SK), Co., Ltd., Songkhla 90110, Thailand.

3) AOAC [10].

4) Expressed as a percentage of crude glycerin dry matter.

\section{Feed intake and growth performance}

Feed was offered for ad libitum consumption twice daily in two equal portions at 0800 and $1600 \mathrm{~h}$ for 90 days. The amount of TMR offered and orts was recorded daily for each goat and the offered amount was adjusted to ensure approximately $10 \%$ of orts after feeding. Before morning feeding, $10 \%$ of orts of each animal were sampled in order to monitor dry matter intake (DMI). The feed efficiency was calculated as the ratio between average daily gain $(\mathrm{ADG}, \mathrm{kg})$ and $\mathrm{DMI}(\mathrm{kg})$. To evaluate growth performance, animals were weighed upon arrival, at the end of adaptation period, and every $14 \mathrm{~d}$ until slaughter.

\section{Chemical analyses}

Samples of feed and orts were composited and at the end of the experiment and dried in a forced-air oven at $55^{\circ} \mathrm{C}$ for 72 $\mathrm{h}$ and ground to a mesh size of $1 \mathrm{~mm}$ [10]. The DM concentration was determined by drying the material in an oven at $105^{\circ} \mathrm{C}$ for $24 \mathrm{~h}$, and ash content was obtained by sample combustion in a muffle furnace at $600^{\circ} \mathrm{C}$ for $3 \mathrm{~h} \mathrm{[9]} \mathrm{to} \mathrm{determine}$ the organic matter $(\mathrm{OM})$. Nitrogen concentration was determined using the micro-Kjeldahl method [9] and CP content was estimated multiplying $\mathrm{N}$ content by 6.25 . The EE content was determined by extraction with petroleum ether in a Soxhlet apparatus for $4 \mathrm{~h}$. The acid detergent lignin (ADL), acid detergent fiber (ADF), and neutral detergent fiber (NDF) content were estimated according to recommendations of Van Soest et al [11], using a heat stable alpha-amylase, without the use of sodium sulfite and expressed inclusive of residual ash.

\section{Slaughter, carcass evaluation, and sample collection}

At the end of the 90-d experiment, four goats from each treatment were randomly selected for slaughter after a 16-h solid fasting period and BWs were recorded to determine the slaughter BW. Animals were transported to Prince of Songkla University Goat Unit's experimental abattoir and were slaughtered according to the standard slaughter procedures described in Thai Agricultural Standard TAS 6006 [12]. Bleeding was performed by severing the carotid arteries and jugular veins immediately after stunning. After evisceration, carcasses were weighed to determine the hot carcass weight (HCW). Directly after slaughter, noncarcass components (skin, head, feet, lung, heart, liver, spleen, kidneys, kidney fat, and gastrointestinal tract fat) were removed and weighed. The stomach (rumen, reticulum, omasum, and abomasum) and postruminal tract (small intestine and large intestine) were removed and weighed separately. The contents of the stomach and postruminal tract were removed, washed, and weighed to obtain the weight of the empty stomach and postruminal tract. The carcass yield percentage was calculated as 100 (hot carcass weight/slaughter weight). Carcasses were refrigerated at approximately $4^{\circ} \mathrm{C}$ for $24 \mathrm{~h}$. After the post mortem chill period, the cold carcass weight (CCW) and cold carcass yield were determined. Carcass length and width were measured. The carcasses were split longitudinally in two parts. The right sides of the carcasses were cut into eight pieces (loin, hind leg, chump, rack, should, fore leg, breast, and neck) according to Thai Agricultural Standard TAS 6006 [11] and were weighed, separately. Individual parts were then dissected into lean meat, bone, trimmings and weighed, separately. The muscular longissimus dorsi (LD) area was made on the left cut surface (of the chilled carcass) between rib 12 and 13 . The $\mathrm{LD}$ (the section between the last lumbar and the first sacral vertebrae) were collected. These cuts of meat and two per animal were labeled and frozen immediately after collection for later measurement of the chemical composition, meat color and shear force characteristics. 


\section{Meat color and $\mathrm{pH}$}

The initial $\mathrm{pH}$ was measured between the 12th and 13th ribs in the center of the Longissimus muscle (LM), approximately 45 min after slaughter, using a digital penetration $\mathrm{pH}$ meter model AG 8603 (Mettler Toledo, AG 8603, Greifensee, Switzerland). Muscle surface color was measured objectively using a Hunter Lab Miniscan Plus Spectrocolorimeter on the same cut surface the LD. Instrumental color measurements were recorded for $\mathrm{L}^{*}$ (measures darkness to lightness; lower $\mathrm{L}^{*}$ indicates a dark color), $\mathrm{a}^{*}$ (measures redness; higher $\mathrm{a}^{*}$ value indicates a redder color), and $\mathrm{b}^{*}$ (measures yellowness; higher $\mathrm{b}^{*}$ value indicates a yellower color) at 3 locations of exposed lean to obtain a representative reading. To determine shear force, samples were defrosted at room temperature until their internal temperature reached $2^{\circ} \mathrm{C}$ to $5^{\circ} \mathrm{C}$. After weighing, samples were trimmed, and thin sections from the lateral and extremities were removed; 4 samples, parallel to the muscle fibers and having $1 \mathrm{~cm}$ of thickness and $5 \mathrm{~cm}$ of length were obtained, to measure the shear force in a texture analyzer (TAXTPlus-Texture Analyzer, with a Warner-Bratzler Blade probe, Texture Expert Exponent-Stable Micro Systems software, Ltd in Godalming, Surrey, UK. SMS). For each sample, 6 shear force results were obtained. Samples of LD muscle were subjected to proximate analysis following the standard methods of AOAC [11].

\section{Statistical analysis}

All data were analyzed using SAS (SAS Institute, Inc., Cary, NC, USA) software. The GLM procedure was used to analyze the fixed effects of treatment on intake, performance, carcass and meat quality traits, with animal serving as the experimental unit. Data were analyzed using the model:

$$
\mathrm{Y}_{\mathrm{ij}}=\mu+\mathrm{M}_{\mathrm{i}}+\varepsilon_{\mathrm{ij}}
$$

Where $Y_{i j}$ is dependent variable; $\mu$ is the overall mean, $M_{i}$ is effect of the level of CGWVO (i=0\%,2\%,4\%, and 6\% DM), and $\varepsilon_{\mathrm{ij}}$ is the residual effect. Results are presented as mean values with the standard error of the means. The significant differences $(p \leq 0.05)$ between means were determined by Duncan's multiple comparison tests. Orthogonal polynomials for CGWVO responses were determined by linear, quadratic, and cubic effects.

\section{RESULTS AND DISCUSSION}

\section{Chemical composition of feeds}

The ingredients and chemical compositions of the experimental diets and CGWVO are presented in Table 1 and Table 2, respectively. Experimental diets contained similar concentrations of $\mathrm{DM}, \mathrm{OM}, \mathrm{CP}, \mathrm{NFC}, \mathrm{ADF}$, and $\mathrm{ADL}$ but varying amount of ether extract (EE) and NDF. The amount of EE was slightly higher as the level of CGWVO increased in the diets, ranging from $1.95 \%$ to $6.06 \%$, whereas NDF content decreased as the proportion of CGWVO in diets increased due to feeding less corn grain, ranging from $40.26 \%$ to $46.08 \% \mathrm{DM}$, respectively. The differences among concentrate mixed diets in $\mathrm{EE}$ and NDF concentrations can be related to differences in the ingredients used in diet formulation (Table 1) especially high contents of EE in CGWVO (47.78\%) (Table 2).

\section{Intake and growth performance}

The effects of CGWVO substitution of corn grain in the diets on growth performance of finishing goats are presented in $\mathrm{Ta}$ ble 3. Overall mean final BW, weight gain, feed intakes, and nutrient intake for the four diets in terms of total DMI (\% BW and $\mathrm{g} / \mathrm{kg} \mathrm{BW}^{0.75}$ ), OMI, CPI, NDFI, and ADFI were significantly altered $(\mathrm{p}<0.05)$ by levels of CGWVO; goats receiving $6 \%$ of CGWVO had linearly lower final BW, weight gain, daily DMI (\% BW and $\mathrm{g} / \mathrm{kg} \mathrm{BW}{ }^{0.75}$ ) and nutrient intake than those treatments. Likewise, ADG and feed efficiency of goats were changed $(\mathrm{p}<0.05)$ by inclusion of CGWVO in the diets; goats receiving $6 \%$ of CGWVO had lower ADG and feed efficiency than other those fed of CGWVO. This is supported by previous studies $[13,14]$. Most of the studies regarding the evaluation of inclusion of CG in diets of ruminant animals $[5,15]$ had used CG with concentrations of fatty acids and methanol lower than $1 \%$. In the present study, CGWVO had $47.78 \%$ of lipids and $4.38 \%$ of methanol. However, the high-risk to health associated to methanol consumption due to inclusion of CG in diets of ruminant animals was not expected since methanol was naturally produced in the ruminal environment as a result of pectin digestion [16]. These authors had demonstrated that a continuous infusion of methanol $(1 \mathrm{~mol} / \mathrm{L})$ at a rate of 10 $\mathrm{mL} / \mathrm{h}$ into the rumen of ovine was completely converted to methane. Our results are in agreement with a study by Lage et al [8] also reported DMI was not altered when lambs fed $3 \%$ DM of CG with high fat and methanol (46.5\% of lipids and $8.7 \%$ of methanol), but a linear decrease when CG increased from $6 \%$ to $12 \%$ DM. This may result from the greater concentration of lipid in diets with the higher concentration of CGWVO was likely to be the main factor that contributed for a reduction of DMI and nutrient digestibility. Ruminant animals are relatively intolerant to high concentrations of fat and feed intake usually decreases as fat content of the diets exceeds $6 \%$ on a DM basis [9]. The study observed that EE content was $6.06 \%$ in diet containing concentration $6 \%$ of CGWVO higher than $4 \%$ DM of CGWVO. Lipids represent a potential stimulator of cholecystokinin which is an appetite suppressant through the gastric emptying inhibition. High lipid diets increase plasma levels of cholecystokinin while the decrease of passage rate of the digesta increases the reticulo-rumen distention leading to a stimulation of cholecystokinin receptors in these gastrointestinal compartments reducing appetite con- 
Table 3. Effects of dietary crude glycerin waste vegetable oil on feed intake and nutrient intake of goats

\begin{tabular}{|c|c|c|c|c|c|c|c|c|}
\hline \multirow{2}{*}{ Item } & \multicolumn{4}{|c|}{ Dietary CGWVO (\% DM) } & \multirow{2}{*}{ SEM } & \multicolumn{3}{|c|}{ Contrasts (p-value) } \\
\hline & 0 & 2 & 4 & 6 & & Linear & Quadratic & Cubic \\
\hline Day on test & 90 & 90 & 90 & 90 & - & & & \\
\hline Pen replicates & 6 & 6 & 6 & 6 & - & & & \\
\hline Initial BW (kg) & 16.88 & 16.60 & 16.83 & 17.10 & 0.18 & 0.33 & 0.15 & 0.56 \\
\hline Final BW (kg) & $27.38^{\mathrm{a}}$ & $28.13^{\mathrm{a}}$ & $27.91^{\mathrm{a}}$ & $24.30^{b}$ & 0.42 & 0.001 & 0.0001 & 0.20 \\
\hline Weight gain $(\mathrm{kg})$ & $10.50^{\mathrm{a}}$ & $11.53^{\mathrm{a}}$ & $11.08^{\mathrm{a}}$ & $7.20^{\mathrm{b}}$ & 0.36 & 0.001 & 0.001 & 0.23 \\
\hline \multicolumn{9}{|l|}{$\mathrm{DMI}(\mathrm{kg} / \mathrm{d})$} \\
\hline Total DMl kg/d & $0.716^{\mathrm{ab}}$ & $0.768^{\mathrm{a}}$ & $0.784^{\mathrm{a}}$ & $0.648^{b}$ & 0.02 & 0.08 & 0.001 & 0.27 \\
\hline DMI (\% BW) & 3.24 & 3.43 & 3.50 & 3.13 & 0.11 & 0.63 & 0.02 & 0.52 \\
\hline DMI (g/kg BW. 0.75$)$ & $70.23^{\mathrm{ab}}$ & $74.74^{\mathrm{ab}}$ & $76.27^{\mathrm{a}}$ & $66.85^{b}$ & 2.32 & 0.41 & 0.01 & 0.45 \\
\hline \multicolumn{9}{|l|}{ Nutrient intake $(\mathrm{kg} / \mathrm{d})$} \\
\hline OMI (kg/d) & $0.670^{\mathrm{ab}}$ & $0.721^{\mathrm{a}}$ & $0.737^{\mathrm{a}}$ & $0.606^{b}$ & 0.02 & 0.08 & 0.001 & 0.25 \\
\hline $\mathrm{CPI}(\mathrm{kg} / \mathrm{d})$ & $0.110^{\mathrm{ab}}$ & $0.117^{\mathrm{a}}$ & $0.120^{\mathrm{a}}$ & $0.100^{b}$ & 0.003 & 0.07 & 0.001 & 0.27 \\
\hline $\operatorname{NDFI}(\mathrm{kg} / \mathrm{d})$ & $0.315^{\mathrm{a}}$ & $0.325^{\mathrm{a}}$ & $0.299^{\mathrm{a}}$ & $0.253^{b}$ & 0.009 & 0.0001 & 0.001 & 0.73 \\
\hline $\operatorname{ADFI}(\mathrm{kg} / \mathrm{d})$ & $0.139^{a b}$ & $0.153^{\mathrm{a}}$ & $0.156^{\mathrm{a}}$ & $0.123^{b}$ & 0.004 & 0.04 & 0.0001 & 0.22 \\
\hline $\operatorname{ADG}(\mathrm{kg} / \mathrm{d})$ & $0.118^{a}$ & $0.128^{\mathrm{a}}$ & $0.125^{\mathrm{a}}$ & $0.080^{b}$ & 0.004 & 0.0001 & 0.0001 & 0.14 \\
\hline $\mathrm{G}: \mathrm{F}(\mathrm{kg} / \mathrm{kg})$ & $0.164^{\mathrm{a}}$ & $0.167^{\mathrm{a}}$ & $0.157^{\mathrm{a}}$ & $0.124^{b}$ & 0.006 & 0.001 & 0.01 & 0.74 \\
\hline
\end{tabular}

CGWVO, crude glycerin from waste vegetable oil; DM, dry matter; SEM, standard error of the mean $(n=6)$; BW, body weight; DMI, dry matter intake; OMI, organic matter intake; CPI, crude protein intake; NDFI, neutral detergent fiber intake; ADFI, acid detergent fiber intake; ADG, average daily gain; G:F, gain-to-feed.

${ }^{a-b}$ Means within rows followed with different superscript letters are statistically different $(p<0.05)$.

sequently. According to Doreau et al [17], the fatty acids may reduce the nutrient digestibility in the ruminal environment and thus reduce the DMI. Jenkins [18] reported that inclusion of lipids in ruminant diets could negatively affect the NDF digestibility and animal performance. In addition, glycerol supplementation affects negatively the digestion of the more fibrous fraction of the feed [19]. Thus, the association of CGWVO with higher content of crude fat in diets decreased the DMI and digestibility by the animals. Indeed, substituting corn with high levels of glycerin was reported to adversely affect ruminal fermentation through reducing fiber digestion, acetate production, and bacterial populations [20]. Moreover, Roger et al [21] demonstrated that introducing glycerol to the ruminal ecology reduced cellulolytic activity of ruminal bacteria.

\section{Carcass characteristics and meat traits}

The effects of treatment diets on carcass characteristics are presented in Table 4. A significant effect was observed for the $\mathrm{HCW}, \mathrm{CCW}$, and dressing percentage $(\mathrm{p}<0.05)$; goats receiving $6 \%$ of CGWVO had lower HCW, CCW and dressing percentage than $4 \%$ of CGWVO (quadratic; $p<0.01$ ), while the differences among the diets $0 \%, 2 \%$, and $6 \%$ of CGWVO were not different. Our results are in agreement with a study by Lage et al [8] reported a negative linear effect of CG concentrations on HCW and CCW of lambs when CG with high fat and methanol (46.5\% of lipids and $8.7 \%$ of methanol) increased from $6 \%$ to $12 \%$ DM. However, there are no information about the feeding trial of CGWVO were evaluated by goats. Carcass yield is directly affected by carcass weight [22]. Thus, animals fed diets with higher concentrations of CGWVO had lighter carcasses and consequently lower carcass yield. On the other hand, diets with low fat levels may increase the dressing percentage, quality and yield grade of the carcass while the high fat content diets tend to decrease these carcass traits [22] as observed in the present study.

However, no effects of CGWVO concentrations were observed on cold carcass dressing percentage, carcass length, carcass width, LM area, and Warner-Bratzler shear force (WBSF), which presented average values of $49.3 \%, 60.2 \mathrm{~cm}$, $25.8 \mathrm{~cm}, 12.2 \mathrm{~cm}, 3.4 \mathrm{~kg} / \mathrm{cm}^{2}$ respectively (Table 4 ). Cold carcass dressing percentage was similar in all goats and within the previously published range of $37 \%$ to $55 \%$ [23]. For the warm dressing percentage in this study was similar to the one reported for crossbred male (Thai Native $\times$ Anglo Nubian) goats [2] who reported that warm dressing percentage in the ranges of $48.9 \%$ to $50.3 \%$ of crossbred male goats. Likewise, the area and WBSF of LM were not affected by treatments. Similarly, Bartoň et al [24] found that a long-term dietary treatment with CG as a replacement of barley meal up to the level of $10 \%$ DM had no significant effect on any of the bull carcass and meat quality traits studied. Nevertheless, the obtained WBSF results $(<4.0 \mathrm{~kg})$ ensure a tenderness that should result in high consumer acceptance [25]. Considering that the Warner-Bratzler force values exceeding $5.5 \mathrm{~kg}$ would often be considered objectionably tough by both trained panel and consumers [26]. In addition, inclusion with CGWVO did not affect back fat thickness $(0.7 \pm 0.1), 45 \mathrm{~min} \mathrm{pH}(6.6 \pm 0.04), 24 \mathrm{~h} \mathrm{pH}(6.1 \pm 0.1)$, 45 min temperature $\left(34.2^{\circ} \mathrm{C} \pm 0.4^{\circ} \mathrm{C}\right)$, and also colorimetric 
Table 4. Effects of dietary crude glycerin waste vegetable oil on carcass characteristics of finishing goats

\begin{tabular}{|c|c|c|c|c|c|c|c|c|}
\hline \multirow{2}{*}{ Item } & \multicolumn{4}{|c|}{ Dietary CGWVO (\% DM) } & \multirow{2}{*}{ SEM } & \multicolumn{3}{|c|}{ Contrasts ( $p$-value) } \\
\hline & 0 & 2 & 4 & 6 & & Linear & Quadratic & Cubic \\
\hline $\mathrm{HCW}(\mathrm{kg})$ & $13.00^{\mathrm{ab}}$ & $13.55^{\mathrm{ab}}$ & $13.72^{\mathrm{a}}$ & $11.85^{b}$ & 0.44 & 0.12 & 0.02 & 0.40 \\
\hline $\mathrm{CCW}(\mathrm{kg})$ & $12.85^{\mathrm{ab}}$ & $13.40^{\mathrm{ab}}$ & $13.57^{\mathrm{a}}$ & $11.60^{b}$ & 0.43 & 0.09 & 0.01 & 0.38 \\
\hline Warm dressing percentage (\%) & $49.92^{\mathrm{ab}}$ & $50.31^{\mathrm{ab}}$ & $50.69^{\mathrm{a}}$ & $49.19^{b}$ & 0.43 & 0.34 & 0.04 & 0.34 \\
\hline Cold dressing percentage (\%) & 49.25 & 49.76 & 50.14 & 48.13 & 0.52 & 0.22 & 0.03 & 0.34 \\
\hline Carcass length $(\mathrm{cm})$ & 60.25 & 61.23 & 60.25 & 59.01 & 0.82 & 0.21 & 0.19 & 0.64 \\
\hline Carcass width (cm) & 26.25 & 26.50 & 25.75 & 24.51 & 0.64 & 0.07 & 0.26 & 0.86 \\
\hline LM area $\left(\mathrm{cm}^{2}\right)$ & 11.65 & 12.37 & 12.32 & 12.29 & 0.79 & 0.60 & 0.63 & 0.82 \\
\hline WBSF $\left(\mathrm{kg} / \mathrm{cm}^{2}\right)$ & 3.59 & 3.41 & 3.18 & 3.43 & 0.36 & 0.20 & 0.40 & 0.17 \\
\hline Back fat thickness (cm) & 0.68 & 0.73 & 0.78 & 0.69 & 0.19 & 0.18 & 0.37 & 0.34 \\
\hline $\mathrm{pH}^{45 \min 1)}$ & 6.61 & 6.54 & 6.57 & 6.63 & 0.07 & 0.22 & 0.25 & 0.19 \\
\hline $\left.\mathrm{pH}^{24 \mathrm{~h}} 2\right)$ & 6.12 & 6.05 & 6.00 & 6.02 & 0.03 & 0.21 & 0.26 & 0.20 \\
\hline Temperature ${ }^{45 \min }$ & 34.21 & 33.58 & 34.60 & 34.35 & 0.52 & 0.31 & 0.42 & 0.50 \\
\hline \multicolumn{9}{|l|}{ Color of LM $^{3)}$} \\
\hline$L^{*}$ & 37.21 & 37.20 & 36.75 & 37.95 & 1.04 & 0.87 & 0.25 & 0.54 \\
\hline$a^{*}$ & 12.11 & 11.88 & 11.11 & 11.83 & 0.50 & 0.24 & 0.80 & 0.48 \\
\hline$b^{*}$ & 9.54 & 9.46 & 9.15 & 9.29 & 0.77 & 0.39 & 0.24 & 0.35 \\
\hline
\end{tabular}

CGWVO, crude glycerin from waste vegetable oil; DM, dry matter; SEM, standard error of the mean $(n=4)$; HCW, hot carcass weight; CCW, cold carcass weight; LM, Longissimus muscle area, $\mathrm{cm}^{2}$ from Longissimus dorsi; WBSF, Warner-Bratzler shear force.

1) $\mathrm{pH}$ measurements taken at $45 \mathrm{~min}$ after slaughter.

2) $\mathrm{pH}$ measurements taken at $24 \mathrm{~h}$ after slaughter.

3) $L^{*}$ values are a measure of lightness (higher value indicates a lighter color); $a^{*}$ values are a measure of redness (higher value indicates a redder color); $b^{*}$ values are a measure of yellowness (higher value indicates a more yellow color), by $\mathrm{ClE}=$ Complete international commission on illumination (Hunter color flex).

${ }^{a-b}$ Means within rows followed with different superscript letters are statistically different $(p<0.05)$.

parameters of $\operatorname{LD}\left(37.3 \pm 0.5,11.7 \pm 0.4\right.$, and $9.4 \pm 0.2$, for $L^{\star}, a^{*}$, and $b^{*}$, respectively) among treatments. The $\mathrm{pH} 45 \mathrm{~min}$ and $24 \mathrm{~h}$ of LM muscle, within the range recorded in the studies reviewed by Webb et al [27], was not affected by dietary treatments. The $\mathrm{pH}$ value of the muscle after slaughter is one of the most important factors that affect meat quality, because the $\mathrm{pH}$ can influence the tenderness, color and water retention capacity. This process involves the depletion of muscle glycogen stores with the production and accumulation of lactic acid. This process also triggers rigor mortis, which in sheep or goat carcasses occurs when the $\mathrm{pH}$ is between 5.6 and 5.8 for the Longissimus muscle. In this study, the $\mathrm{pH}$ of Longissimus muscle $45 \mathrm{~min}$ and $24 \mathrm{~h}$ after slaughter averaged 6.6 and 6.1. It can be inferred from these low values that no DFD meat (dry, firm and dark muscle) was observed, proving also by the high $L^{*}$ values found $45 \mathrm{~min}$ after slaughter, reflecting on high values of $a^{\star}$ and $b^{\star}$. Color is an important meat quality trait because the first impression consumers have on any meat product is based on its color [28]. The average values observed in the current study for each of these variables were 36.7 to $37.2,11.1$ to 12.1 and 9.1 to 9.5 , respectively for $L^{*}, a^{*}$, and $b^{*}$. Similar value for color have been previously reported by Chanjula et al [2]; Adeyemi et al [29] who was observed in goats meat usually presents values from 30.6 to 39.9 for $L^{*}, 11.8$ to 18.0 for $a^{*}$, and 3.3 to 11.54 for $b^{*}$. Postmortem ageing did not affect ( $\mathrm{p}>0.05)$ the $L^{\star}, a^{\star}$, and $b^{\star}$ values of LM muscle from goats.
The lack of differences in carcass characteristics (Table 4) can be explained by the uniformity of the animals in the beginning of feedlot period and the similar laughter weight.

The effects of treatment diets on the carcass cuts of the goats are presented in Table 5. Percentage of the chilled carcass weight, loin, chump, rack, shoulder, breast, fore leg, and neck were similar ( $p>0.05)$ for all treatments. However, hind leg was greater (quadratic; $\mathrm{p}<0.01$ ) in goats that received the $6 \%$ of CGWVO treatment (22.8\%) than in those that received the $2 \%$ of CGWVO (21.0\%). It remains unclear whether this was due to the dietary treatment. The present results cannot be compared with other results, because there are few reports on the effects of CGWVO supplementation on carcass cuts. Nevertheless, data from the current study demonstrate that feeding CGWVO up to $6 \%$ of dietary DM may have not a negative impact on commercial cut of goats. By design, no significant effect of dietary CGWVO was observed on chemical composition of LD (Table 6). The mean values of chemical composition of Longissimus muscle, within the range recorded in the studies by Beserra et al [30] reporting DM, ash, CP, and EE levels ranging 22.3 to $24.0,20.5$ to $21.9,1.5$ to 2.7 , and 1.0 to 1.1 , respectively. However, it is noteworthy that LD petroleum ether extract was numerically greater in the animals fed CGWVO. Glucose was previously shown to be quantitatively the primary lipid precursor in intramuscular adipose tissue whereas the relative contribution of acetate to lipogenesis was 
Table 5. Effects of dietary CGWVO crude glycerin waste vegetable oil on carcass cuts of finishing goats

\begin{tabular}{|c|c|c|c|c|c|c|c|c|}
\hline \multirow{2}{*}{ Items } & \multicolumn{4}{|c|}{ Dietary CGWVO (\% DM) } & \multirow{2}{*}{ SEM } & \multicolumn{3}{|c|}{ Contrasts (p-value) } \\
\hline & 0 & 2 & 4 & 6 & & Linear & Quadratic & Cubic \\
\hline \multicolumn{9}{|l|}{ (arcass cuts ${ }^{1)}$} \\
\hline Loin (\%) & 11.24 & 12.50 & 11.34 & 11.22 & 0.54 & 0.61 & 0.21 & 0.16 \\
\hline Hind leg (\%) & $22.18^{\mathrm{ab}}$ & $21.01^{b}$ & $21.68^{\mathrm{ab}}$ & $22.82^{\mathrm{a}}$ & 0.33 & 0.10 & 0.01 & 0.37 \\
\hline Chump (\%) & 7.38 & 7.35 & 6.75 & 6.74 & 0.26 & 0.07 & 0.98 & 0.33 \\
\hline Rack (\%) & 10.10 & 10.91 & 10.68 & 10.49 & 0.51 & 0.33 & 0.97 & 0.56 \\
\hline Shoulder (\%) & 12.36 & 13.82 & 13.71 & 11.98 & 0.90 & 0.76 & 0.10 & 0.98 \\
\hline Fore leg (\%) & 20.50 & 19.67 & 20.29 & 20.65 & 0.60 & 0.69 & 0.32 & .51 \\
\hline Breast (\%) & 10.96 & 9.72 & 10.08 & 10.68 & 0.48 & 0.82 & 0.08 & 0.53 \\
\hline $\operatorname{Neck}(\%)$ & 5.35 & 5.63 & 5.82 & 5.39 & 0.26 & 0.79 & 0.19 & 0.64 \\
\hline
\end{tabular}

CGWVO, crude glycerin from waste vegetable oil; DM, dry matter; SEM, standard error of the mean $(n=4)$.

1) Carcass cuts, as a percentage of chilled carcass weight.

${ }^{a-b}$ Means within rows followed with different superscript letters are statistically different $(p<0.05)$.

greatest in subcutaneous adipose tissue [31]. As glycerin is an important glucogenic substrate, this might give an explanation of the slightly higher levels of intramuscular fat. Unlike in our study, it has been previously reported that glycerin increased ruminal propionic and butyric acid concentrations at the expense of acetic acid concentration [3]. Therefore, lower concentrations of acetic acid as a lipogenic precursor could have been the reason why glycerin supplemented diets reduced in both subcutaneous fat and marbling scores in feedlot heifers fed increasing quantities of CG [13] and decreased LD ether extract values in finishing lambs [6].

\section{IMPLICATIONS}

Based on the results of this experiment, substituting corn grain with CGWVO (63.42\% glycerol and $47.78 \%$ crude fat) up to $4 \%$ of DM in the diets of goats had no effect on feed intake and none on growth performance, carcass, and meat quality traits studies when compared to the control group. However, increasing CGWVO levels at 6\% DM would result more in a slightly lower daily DMI, nutrient intake, and carcass characteristics than in those goats fed on $0 \%$ to $4 \%$ of CGWVO. Thus, in the case of competitive prices, CGWVO may be ef- fectively used as an alternative energy source to substitute for cereals in the diets of goats. However, further research and long-term studies should be conducted to validate the effects of supplementing of CGWVO on milk production and to determine the optimal feeding rates in dairy goats.

\section{CONFLICT OF INTEREST}

We certify that there is no conflict of interest with any financial organization regarding the material discussed in the manuscript.

\section{ACKNOWLEDGMENTS}

The authors would like to express their most sincere gratitude and appreciation to the Department of Animal Science, Faculty of Natural Resources, Prince of Songkla University (PSU) for financial support of this research (Project no. NAT580742S). This work was also supported by Tropical Feed Resources Research and Development Center (TROFREC) and the Increase Production Efficiency and Meat Quality of Native Beef and Buffalo Research Group, Khon Kaen University (KKU).

Table 6. Effects of dietary crude glycerin waste vegetable oil on chemical composition of LD (Longissimus dorsi) muscle of finishing goats

\begin{tabular}{|c|c|c|c|c|c|c|c|c|}
\hline \multirow{2}{*}{ Item } & \multicolumn{4}{|c|}{ Dietary CGWVO (\% DM) } & \multirow{2}{*}{ SEM } & \multicolumn{3}{|c|}{ Contrasts ( $p$-value) } \\
\hline & 0 & 2 & 4 & 6 & & Linear & Quadratic & Cubic \\
\hline \multicolumn{9}{|c|}{ Nutritional composition } \\
\hline DM (\%) & 26.39 & 25.56 & 26.31 & 26.16 & 0.38 & 0.69 & 0.58 & 0.31 \\
\hline Ash (\%) & 1.50 & 1.55 & 1.63 & 1.65 & 0.11 & 0.57 & 0.85 & 0.56 \\
\hline Protein (\%) & 22.30 & 22.19 & 22.25 & 22.12 & 0.29 & 0.61 & 0.50 & 0.98 \\
\hline Ether extract (\%) & 1.48 & 1.58 & 1.89 & 1.72 & 0.18 & 0.11 & 0.69 & 0.32 \\
\hline Calcium (\%) & 0.10 & 0.11 & 0.10 & 0.11 & 0.01 & 0.90 & 0.86 & 0.88 \\
\hline Phosphorous (\%) & 0.66 & 0.64 & 0.63 & 0.69 & 0.07 & 0.78 & 0.25 & 0.67 \\
\hline
\end{tabular}

CGWVO, crude glycerin from waste vegetable oil; DM, dry matter; SEM, standard error of the mean $(n=4)$. 


\section{REFERENCES}

1. Thompson JC, He BB. Characterization of crude glycerin from biodiesel production from multiple feedstocks. Appl Eng Agric 2006;22:261-5.

2. Chanjula P, Pakdeechanuan P, Wattanasit S. Effects of feeding crude glycerin on feedlot performance and carcass characteristics in finishing goats. Small Rumin Res 2015;123:95-102.

3. Rémond B, Souday E, Jouany JP. In vitro and in vivo fermentation of glycerol by ruminal microbes. Anim Feed Sci Technol 1993;41:121-32.

4. AbuGhazaleh AA, Abo El-Nor S, Ibrahim SA. The effect of replacing corn with glycerol on ruminal bacteria in continuous culture fermenters. J Anim Physiol Anim Nutr 2011;95:313-9.

5. Avila-Stagno J, Chaves AV, He ML, et al. Effects of increasing concentrations of glycerol in concentrate diets on nutrient digestibility, methane emissions, growth, fatty acid profiles, and carcass traits of lambs. J Anim Sci 2013;91:829-37.

6. Gunn PJ, Neary MK, Lemenager RP, Lake SL. Effects of crude glycerin on performance and carcass characteristics of finishing wether lambs. J Anim Sci 2010;88:1771-6.

7. Chanjula P, Pongprayoon S, Kongpan S, Cherdthong A. Effects of crude glycerin from waste vegetable oil supplementation on feed intake, ruminal fermentation characteristics, and nitrogen utilization of goats. Trop Anim Health Prod 2016;48:9951004.

8. Lage JF, Paulino PVR, Pereira LGR, et al. Carcass characteristics of feedlot lambs fed crude glycerin contaminated with high concentrations of crude fat. Meat Sci 2014;96:108-13.

9. NRC (Nutrient requirements of small ruminants). 7th edn. Washington, DC, USA: National Academy Press; 2007.

10. AOAC Official methods of analysis. 16th ed. Assoc Off Anal. Chem., Arlington, VA, USA: AOAC International; 1995.

11. Van Soest PJ, Robertson JB, Lewis BA. Methods for dietary fiber neutral detergent fiber, and nonstarch polysaccharides in relation to animal nutrition. J Dairy Sci 1991;74:3583-97.

12. Thai Agricultural Standard (TAS) 6006. Goat meat - general guidelines. National Bureau of Agricultural Commodity and Food Standards, Published in the Royal Gazette Vol. 125 Section 139 D, dated 18 August; 2008.

13. Parsons GL, Shelor MK, Drouillard JS. Performance and carcass traits of finishing heifers fed crude glycerin. J Anim Sci 2009;87:653-7.

14. Ramos MH, Kerley MS. Effect of dietary crude glycerol level on ruminal fermentation in continuous culture and growth performance of beef calves. J Anim Sci 2012;90:892-9.

15. Mach N, Bach A, Devant M. Effects of crude glycerin supplementation on performance and meat quality of Holstein bulls fed high-concentrate diets. J Anim Sci 2009;87:632-8.

16. Pol A, Demeyer DI. Fermentation of methanol in the sheep rumen. Appl Environ Microbiol 1988;54:832-4.
17. Doreau M, Demeyer DI, Van Nevel CJ. Transformation and effects of unsaturated fatty acids in the rumen: consequences on milk fat secretion. In: Welch RAS, Burns DJW, Davis SR, Popay AI, Prosser CG, editors. Milk composition, production and biotechnology. Wallinford, Oxfordshire, UK: CAB International, 1997. pp. 73-92.

18. Jenkins TC. Lipid metabolism in the rumen. J Dairy Sci 1993; 76:3851-63.

19. Südekum K-H, Schröder A, Fiebelkorn S, Schwer R, Thalmann A. Quality characteristics of pelleted compound feeds under varying storage conditions as influenced by purity and concentration of glycerol from biodiesel production. J Anim Feed Sci 2008; 17:120-36.

20. Abo El-Nor S, AbuGhazaleh AA, Potu RB, Hastings D, Khattab MSA. Effects of different levels of glycerol on ruminal fermentation and bacteria. Anim Feed Sci Technol 2010;162:99-105.

21. Roger V, Fonty G, Andre C, Gouet P. Effects of glycerol on the growth, adhesion, and cellulolytic activity of ruminal cellulolytic bacteria and anaerobic fungi. Curr Microbiol 1992;25:197201.

22. Owens FN, Gardner BA. A review of the impact of feedlot management and nutrition on carcass measurements of feedlot cattle. J Anim Sci 2000;77(E-Suppl.):1-18.

23. Ensminger ME. Sheep and goat science, 6th ed. Danville, IL, USA: Interstate Publisher, Inc.; 2002.

24. Bartoñ L, Bureš D, Homolka P, et al. Effects of long-term feeding of crude glycerine on performance, carcass traits, meat quality, and blood and rumen metabolites of finishing bulls. Livest Sci 2013;153:53-9.

25. Miller M, Carr M, Ramsey C, Crocket K, Hoover L. Consumer thresholds for establishing the value of beef tenderness. J Anim Sci 2001;79:3062-8.

26. Shackelford SD, Morgan JB, Cross HR, Savell JW. Identification of threshold levels for Warner-Bratzler shear press in beef top loin steaks. J Muscle Foods 1991;2:289-96.

27. Webb EC, Casey HN, Simela L. Goat meat quality. Small Rumin Res 2005;60:153-66.

28. Farouk MM, Al-Mazeedi HM, Sabow AB, et al. Halal and kosher slaughter methods and meat quality: A review. Meat Sci 2014;98:505-19.

29. Adeyemi KD, Sazili AQ, Ebrahimi M, et al. Effects of blend of canola oil and palm oil on nutrient intake and digestibility, growth performance, rumen fermentation and fatty acids in goats. Anim Sci J 2016;87:1137-47.

30. Beserra FJ, Madruga MS, Leite AM, da Silva EMC, Maia EL. Effect of age at slaughter on chemical composition of meat from Moxotó goats and their crosses. Small Rumin Res 2004; 55:77-81.

31. Smith SB, Kawachi H, Choi CB, et al. Cellular regulation of bovine intramuscular adipose tissue development and composition. J Anim Sci 2009;87:E72-E82. 